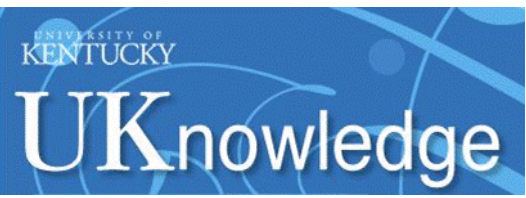

University of Kentucky

UKnowledge

\title{
Biologic Cycling of Silica across a Grassland Bioclimosequence
}

S. W. Blecker

Colorado State University

Rebecca L. McCulley

University of Kentucky, rebecca.mcculley@uky.edu

O. A. Chadwick

University of California, Santa Barbara

E. F. Kelly

Colorado State University

Follow this and additional works at: https://uknowledge.uky.edu/pss_facpub

Part of the Plant Sciences Commons

Right click to open a feedback form in a new tab to let us know how this document benefits you.

\section{Repository Citation}

Blecker, S. W.; McCulley, Rebecca L.; Chadwick, O. A.; and Kelly, E. F., "Biologic Cycling of Silica across a Grassland Bioclimosequence" (2006). Plant and Soil Sciences Faculty Publications. 39.

https://uknowledge.uky.edu/pss_facpub/39

This Article is brought to you for free and open access by the Plant and Soil Sciences at UKnowledge. It has been accepted for inclusion in Plant and Soil Sciences Faculty Publications by an authorized administrator of UKnowledge. For more information, please contact UKnowledge@lsv.uky.edu. 


\section{Biologic Cycling of Silica across a Grassland Bioclimosequence}

Digital Object Identifier (DOI)

http://dx.doi.org/10.1029/2006GB002690

Notes/Citation Information

Published in Global Biogeochemical Cycles, v. 20, no. 3, article GB3023, p. 1-11.

Copyright 2006 by the American Geophysical Union.

The copyright holder has granted permission for posting the article here. 


\title{
Biologic cycling of silica across a grassland bioclimosequence
}

\author{
S. W. Blecker, ${ }^{1,2}$ R. L. McCulley, ${ }^{3}$ O. A. Chadwick, ${ }^{4}$ and E. F. Kelly ${ }^{1}$ \\ Received 10 January 2006; revised 8 May 2006; accepted 6 June 2006; published 20 September 2006.
}

[1] The dynamics of biologic Si cycling in grassland ecosystems are largely unknown and likely to impact mineral weathering rates regionally and diatom productivity globally; key regulatory processes in the global Si cycle are closely tied to the global carbon cycle. Across a bioclimatic sequence spanning major grassland ecosystems in the Great Plains, soil biogenic silica depth distributions are similar to that of soil organic carbon; however, unlike soil organic carbon, quantities of soil biogenic silica decrease with increasing precipitation, despite an increase in annual biogenic inputs through litterfall across the same gradient. Though comprising only $1-3 \%$ of the total Si pool, faster turnover of biogenic Si and annual cycling by grasses should positively impact mineral dissolution. Our results suggest that the largest reservoir of biogenic Si in terrestrial ecosystems resides in soils, and emphasize the potential significance of grasslands in the global biogeochemical cycle of $\mathrm{Si}$.

Citation: Blecker, S. W., R. L. McCulley, O. A. Chadwick, and E. F. Kelly (2006), Biologic cycling of silica across a grassland bioclimosequence, Global Biogeochem. Cycles, 20, GB3023, doi:10.1029/2006GB002690.

\section{Introduction}

[2] Silicon is the most abundant element in the earth's crust after oxygen, plays a key role in earth surface processes, and is an important nutrient and structural component of marine and terrestrial organisms. The fate and mobility of silica in terrestrial systems impacts soil development [Kelly et al., 1998] and buffering capacity [Drever, 1994], as well as the long-term regulation of atmospheric carbon dioxide [Berner, 1992; Chadwick et al., 1994]. Primary mineral dissolution and formation of secondary minerals is a primary control on fluxes to aqueous systems [White and Blum, 1995; Gaillardet et al., 1999], but few assessments of silica export include the role of biogenic silica stored in soils and vegetation, [e.g., Berner, 1995; White et al., 1998]. Recently however, several pivotal papers highlight the importance of plant uptake and cycling on silica activity and mineral stability in soils subjected to intense chemical weathering [Lucas et al., 1993; Alexandre et al., 1997; Markewitz and Richter, 1998; Meunier et al., 1999; Derry et al., 2005].

[3] Plants extract silica from the soil as monosilicic acid, transport it via the transpiration stream, and transform the soluble silica into opal that is stored in cell walls, cell luminas, and intercellular spaces typically near evaporating

\footnotetext{
${ }^{1}$ Department of Soil and Crop Sciences, Colorado State University, Fort Collins, Colorado, USA.

${ }^{2}$ Now at Department of Forest Resources, University of Idaho, Moscow, Idaho, USA.

${ }^{3}$ Department of Plant and Soil Science, University of Kentucky, Lexington, Kentucky, USA.

${ }^{4}$ Department of Geography, University of California, Santa Barbara, California, USA.

Copyright 2006 by the American Geophysical Union. 0886-6236/06/2006GB002690
}

surfaces forming phytoliths [Jones and Handreck, 1967; Raven, 1983; Sangster and Hodson, 1992; Epstein, 1999], whose morphologies can be diagnostic of plant species [Piperno, 1988]. Phytoliths are present in most plants, ranging in content from $0.5 \%$ or less in most dicotyledons, $1-3 \%$ in typical dryland grasses, and up to $10-15 \%$ in some wetland plant species [Epstein, 1994]. Upon plant death and decomposition phytoliths are deposited in soil where their abundance is regulated by the balance between plant inputs and dissolution outputs which are controlled by the degree of chemical weathering [Alexandre et al., 1997], soil mineralogy [Dahlgren et al., 1993], and bioclimatic conditions [Kelly et al., 1993]. Phytolith contribution to the overall terrestrial $\mathrm{Si}$ cycle is magnified by the rapidity of plant production cycles and by their solubility (expressed as molarity), which is similar to amorphous silica $\left(10^{-2.74}\right)$ and falls between silica glass $\left(10^{-2.71}\right)$, and quartz $\left(10^{-4.00}\right)$ [Lindsay, 1979].

[4] Research on forested ecosystems demonstrates a prominent biologic role in silica storage and export from terrestrial environments [Lucas et al., 1993; Meunier et al., 1999; Farmer et al., 2005]. In temperate deciduous forests, $>80 \%$ of soluble silica was derived from biogenic silica, compared to $<20 \%$ in coniferous forest systems [Bartoli, 1983; Markewitz and Richter, 1998]. In tropical forests the contribution of biogenic silica to soil solution, soil mineral formation and stream export can exceed the contribution from weathering of primary minerals [Alexandre et al., 1997; Derry et al., 2005] (but for a counter example see Ziegler et al. [2005]. It is clear that omitting biogenic Si contributions to terrestrial silica cycle underestimates the role of vegetation and soil-stored phytoliths as a control on $\mathrm{Si}$ export [Conley, 2002].

[5] Although grasses have high phytolith content [Epstein, 1994] and their paleoenvironmental significance have been 


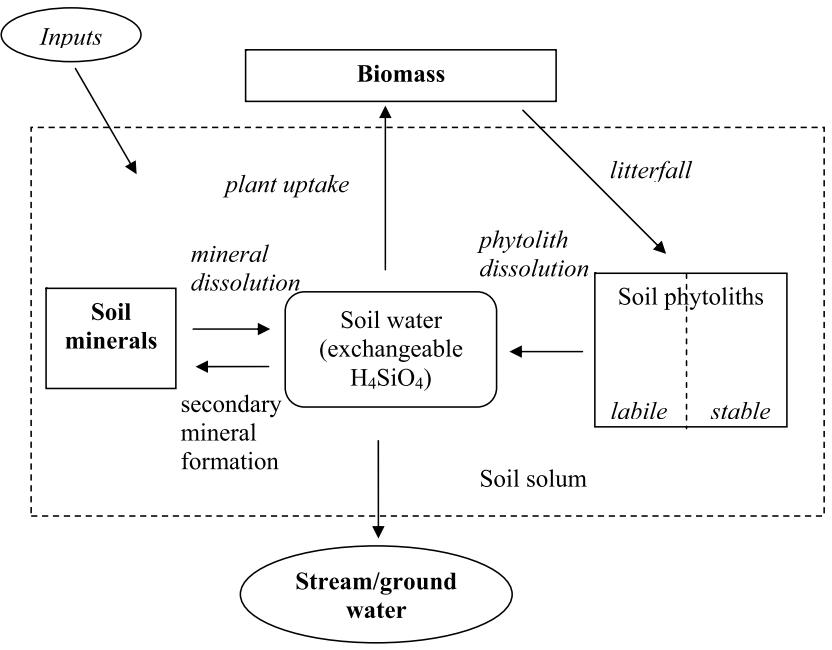

Figure 1. Conceptual model of major pools and fluxes associated with the terrestrial grassland Si cycle [after Bartoli, 1983; Alexandre et al., 1997]. Bold items were directly measured in this study; italicized items were estimated.

studied for decades (e.g., for North American ecosystems [Wilding and Drees, 1971; Kelly et al., 1993; Blinnikov et $a l ., 2002])$, their role in the overall terrestrial biogeochemical Si cycle has not been quantified. If, as expected, grassland ecosystems are a particularly large and active reservoir of biogenic silica, the global expansion of grasslands during the late Neogene [Axelrod, 1985; Stromberg, 2004] likely had important consequences for both marine and terrestrial Si cycles [Kidder and Gierlowski-Kordesch, 2005], and the long-term global carbon cycle [Conley, 2002]. Despite its potential significance, grassland biogenic Si pool size, cycling, and impact on mineral weathering and Si export are largely unknown.

[6] The objectives of this research therefore were: (1) to determine how quantities of biogenic Si stored in annual plant biomass and soils vary as a function of climate and grassland type across temperate American Great Plains ecosystems; (2) to determine the range in biogeochemical behavior (turnover) of biogenic Si in grassland soils; and (3) to estimate the potential significance of grasslands in mobilizing and storing biogenic silica from terrestrial ecosystems. Figure 1 provides a schematic view of the conceptual model that guided the research.

\section{Site Description}

[7] A bioclimosequence [Jenny, 1941] spanning a precipitation gradient from 350 to $1100 \mathrm{~mm}$ in the Central Great Plains was sampled from the short grass steppe of eastern Colorado to the tall grass prairie of western Missouri (Table 1 and Figure 2). To minimize the influence of slope and aspect across the sampling gradient, relatively flat upland sites were selected: two in short grass, three in mixed grass and two in tall grass communities. Sites were subject to grazing but not cultivation. Soils were derived from residual sedimentary rock and loess [Mason et al., 2003; Roberts et al., 2003] and range from drier (Aridic Argiustoll) to wetter (Typic Hapludoll) Mollisols across the gradient [Soil Survey Staff, 1996]. Given the geomorphic history along the gradient and radiocarbon dates, we have estimated soil age at 10-30 ky [Blecker et al., 1997; Oviatt, 1998]. Plant communities varied with mean annual precipitation (MAP). Bouteloua gracilis and Buchloe dactyloides dominated the short grass sites (SGS and ARIK), Bouteloua gracilis, Buchloë dactyloides, Festuca $s p$. the drier mixed grass sites (SVR and HAYS), Schizachyrium scoparium and Andropogon gerardii the wetter mixed grass site (Wilson), and Andropogon gerardii the tall grass sites (KONZA and WKT).

[8] Quantities of phytolith in the surface horizons of grass dominated ecosystems of the Great Plains generally reflect above ground versus below ground inputs of biomass. Both stable $\mathrm{C}$ and radiometric isotope composition of phytoliths in the A horizons suggest equilibrium with modern plant community assemblages [Kelly, 1989; Kelly et al., 1991].

\section{Field Methodology}

[9] To quantify the degree of chemical weathering along the precipitation gradient, soils were sampled to the base of the C horizon (SGS, ARIK, SVR, HAYS) or bedrock (WILSON, KONZA, WKT) during the summer of 2003. Pedons were described and sampled by genetic horizon [Soil Survey Staff, 1992]. Approximately $1 \mathrm{~kg}$ of soil was sampled from each horizon. To examine soil phytolith

Table 1. Characteristics for the Seven Sites Comprising the Great Plains Bioclimosequence ${ }^{\mathrm{a}}$

\begin{tabular}{|c|c|c|c|c|c|c|c|}
\hline & $\begin{array}{c}\text { SGS Short Grass } \\
\text { Steppe-LTER }\end{array}$ & $\begin{array}{c}\text { ARIK } \\
\text { Arikaree-TNC }\end{array}$ & $\begin{array}{l}\text { SV Smokey } \\
\text { Valley-TNC }\end{array}$ & $\begin{array}{c}\text { HAYS Fort } \\
\text { Hays State Univ. }\end{array}$ & $\begin{array}{l}\text { WILSON Wilson } \\
\text { Lake State Park }\end{array}$ & $\begin{array}{c}\text { KONZA Konza } \\
\text { Prairie-LTER }\end{array}$ & $\begin{array}{c}\text { WKT Wah-Kon- } \\
\text { Tah-TNC } \\
\end{array}$ \\
\hline Latitude & $40^{\circ} 51.99 \mathrm{~N}$ & $39^{\circ} 45.02 \mathrm{~N}$ & $38^{\circ} 53.11 \mathrm{~N}$ & $38^{\circ} 52.44 \mathrm{~N}$ & $38^{\circ} 56.33 \mathrm{~N}$ & $39^{\circ} 05.48 \mathrm{~N}$ & $37^{\circ} 53.52 \mathrm{~N}$ \\
\hline Longitude & $104^{\circ} 41.47 \mathrm{~W}$ & $102^{\circ} 28.68 \mathrm{~W}$ & $100^{\circ} 57.63 \mathrm{~W}$ & $99^{\circ} 23.15 \mathrm{~W}$ & $98^{\circ} 40.40 \mathrm{~W}$ & $96^{\circ} 34.12 \mathrm{~W}$ & $93^{\circ} 58.58 \mathrm{~W}$ \\
\hline Elevation, $\mathrm{m}$ & 1,650 & 1,220 & 879 & 610 & 536 & 406 & 287 \\
\hline $\mathrm{MAP}^{\mathrm{b}}{ }^{\mathrm{mm}}$ & 344 & 462 & 502 & 575 & 650 & 884 & 1110 \\
\hline $\mathrm{MAT}^{\mathrm{b}}{ }^{\circ} \mathrm{C}$ & 9.3 & 9.7 & 10.8 & 11.9 & 12.3 & 12.7 & 13.1 \\
\hline ANPP, kg/ha & $940 \pm 230$ & $1030 \pm 560$ & $1850 \pm 880$ & $2660 \pm 850$ & $2960 \pm 170$ & $3910 \pm 630$ & $4240 \pm 230$ \\
\hline Vegetation type & short grass steppe & short grass steppe & mixed grass & mixed grass & mixed grass & tall grass & tall grass \\
\hline Soil subgroup ${ }^{c}$ & aridic argiustoll & aridic argiustoll & typic argiustoll & typic argiustoll & typic calciustoll & udic argiustoll & typic hapludoll \\
\hline
\end{tabular}

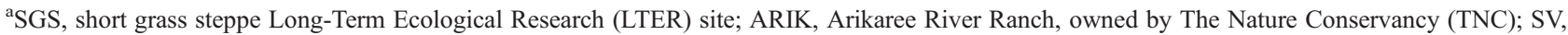
Smokey Valley River Ranch owned by the TNC; HAYS, Hays Range Area, owned by Fort Hays State University; WILSON, owned by Wilson Lake State Park; KONZA, Konza Prairie Research Natural Area and LTER site; WKT, Wah-Kon-Tah Natural Area owned by TNC; MAP, mean annual precipitation; MAT, mean annual temperature; ANPP, aboveground net primary productivity, \pm standard error of the mean.

${ }^{\mathrm{b}}$ National Climate Data Center [2002].

'Soil Survey Staff [1996]. 


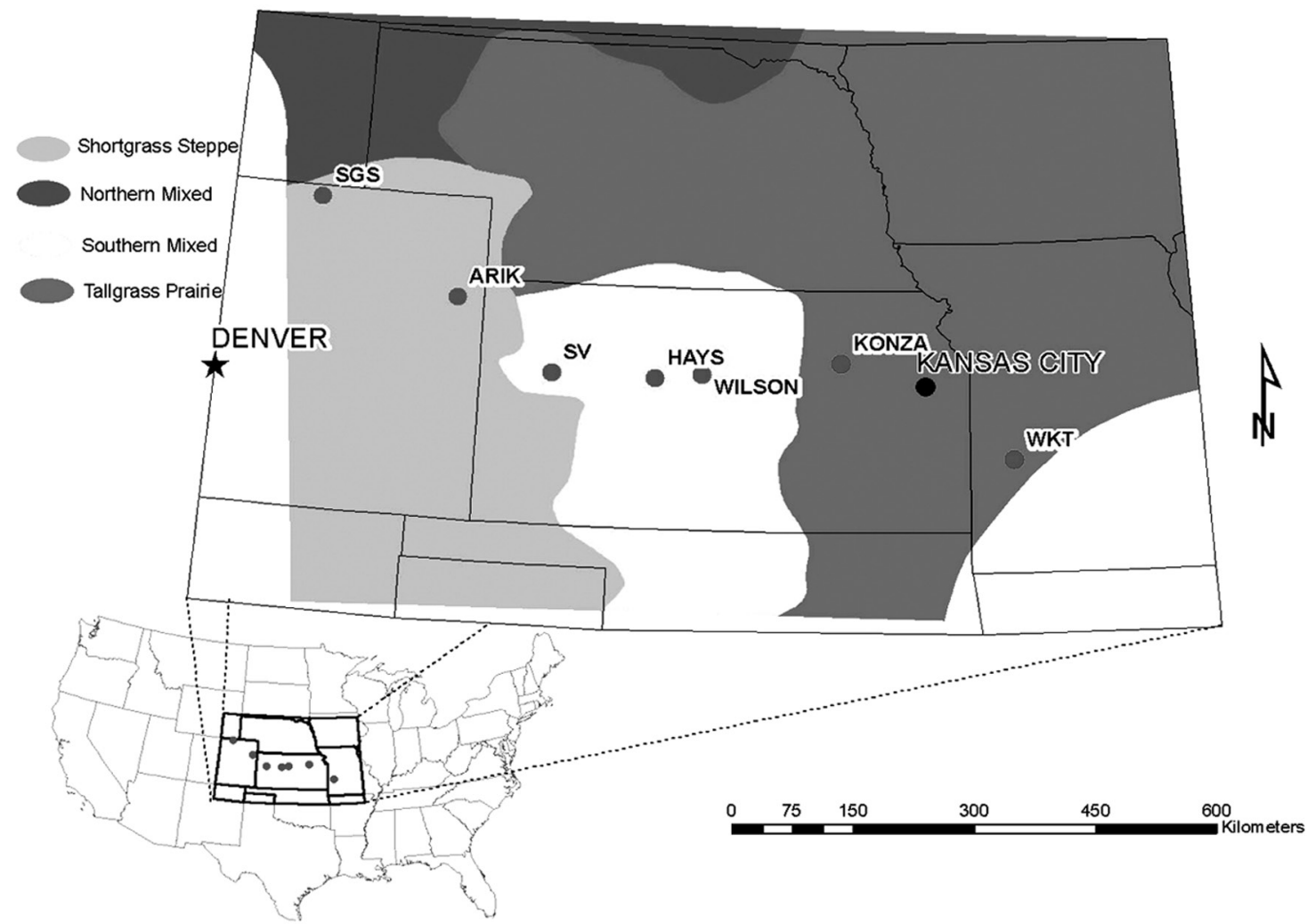

Figure 2. Location map for field sites located along the Great Plains grassland bioclimosequence.

variability, two additional surface horizon samples were taken in a random direction $3 \mathrm{~m}$ from each pedon. Soil peds were removed from each horizon for laboratory bulk density analysis. For plant phytolith analysis, leaf and stem samples of the major grass and forb species were taken adjacent to the soil sampling area. Aboveground annual net primary productivity (ANPP) data was taken from $\mathrm{McC}$ culley and Burke [2004], except for WILSON and WKT, where ANPP was measured by clipping $0.25 \mathrm{~m}^{2}$ quadrats during the 2003 growing season.

[10] Water samples were taken near each sample site approximately every 3 months from spring 2003 through spring 2004 to better estimate the quantity of dissolved $\mathrm{Si}$ inputs (precipitation) and outputs (groundwater, stream water). Particulate Si was not measured but has been shown to be a relatively minor component of total terrestrial $\mathrm{Si}$ export to the oceans ( 5\% [Treguer et al., 1995]). Stream, rain, and groundwater were collected in acid-rinsed lowdensity polyethylene (LDPE) bottles, filtered through $0.4 \mathrm{um}$ polycarbonate filters and stored in acid-washed LDPE bottles prior to analysis. To supplement the water samples, publicly available (United States Geological Survey) USGS hydrologic data (http://waterdata.usgs.gov/nwis/qw) for discharge and water chemistry of nearby streams was used.

\section{Laboratory Methods}

[11] Soil texture was determined on a subsample of $<2-\mathrm{mm}$ unground soil by hydrometer method [Gee and Bauder,
1986]. Soil bulk density was determined by clod method [Blake and Hartge, 1986]. Oven-dried, ball-mill pulverized soil and rock samples were submitted to SGS Mineral Services of Toronto, Canada for total elemental analysis. Samples were ashed at $500^{\circ} \mathrm{C}$ to remove organic matter, fused with Li-metaborate, dissolved in dilute nitric acid and analyzed by inductively coupled plasma, atomic emission spectroscopy. Results are reported on ash-free samples. Internal standards, blind standards and duplicates were analyzed for quality control.

[12] Soil phytoliths were extracted by heavy liquid floatation (cadmium iodide/potassium iodide at s.g. $=2.3$ ) from sand (surface horizon only, as negligible phytolith recovery was obtained from subsurface horizons) and silt fractions, and cleaned with dilute hydrochloric acid, hydrogen peroxide, and deionized water in a method adapted from Piperno [1988], Kelly [1990], and Parr [2002]. Oven-dried (105 ${ }^{\circ}$ ), 2-mm sieved soils were treated with sodium acetate (buffered at $\mathrm{pH} 5$ with acetic acid) to remove carbonates, and $30 \%$ hydrogen peroxide to remove organic matter. After rinsing with deionized water, 5\% sodium hexametaphosphate was added and the sample shaken overnight. Sand was separated from the silt and clay fraction by wet sieving through a $53-\mu \mathrm{m}$ screen. Silt was separated from clay by centrifugation and gravity sedimentation. The sand and silt fractions were then rinsed with deionized water, dried overnight and stored in plastic bottles. To obtain phytoliths, a subsample $(2-5 \mathrm{~g})$ of either sand or silt was placed in a $50-\mathrm{mL}$ plastic centrifuge tube along with cadmium iodide/ 
potassium iodide (specific gravity of $2.30 \mathrm{~g} / \mathrm{cm}^{3}$ ). The samples were thoroughly stirred and then centrifuged at $2000 \mathrm{rpm}$ for $10 \mathrm{~min}$. Phytoliths were removed by pipet. Additional stirring and centrifugation was repeated until negligible yield was obtained. Samples were rinsed of the heavy liquid with deionized water. Small amounts of clay obtained during the separation were removed by shaking the phytolith sample in 5\% sodium hexametaphosphate overnight, allowing the phytolith to settle, then siphoning off the suspended clays. Phytoliths were further cleaned in separate steps with $10 \%$ hydrochloric acid and $30 \%$ hydrogen peroxide. After passing through a $0.2-\mu \mathrm{m}$ polycarbonate filter, samples were dried overnight and stored in plastic vials. Subsamples of the soil phytoliths were mounted in immersion oil with a refractive index of 1.51 and examined under light microscope as well as a dissecting scope to ensure that they were not contaminated with other minerals. X-ray diffraction analysis of random phytolith samples corroborated the lack of contamination.

[13] Plant samples were washed to remove soil contamination, dry ashed, then treated to remove non-siliceous material in a method adapted from Piperno [1988], Kelly [1990], and Parr et al. [2001]. A 5- to 10-g sample of ovendried $\left(55^{\circ}-60^{\circ} \mathrm{C}\right)$ plant material was cut into $2-$ to $3-\mathrm{cm}$ lengths, washed in a mixture of $5 \%$ sodium hexametaphosphate, dilute hydrochloric acid and deionized water. After thorough rinsing, the sample was washed in $70 \%$ ethanol, and rinsed again with deionized water. After drying again at $55^{\circ}-60^{\circ} \mathrm{C}$, a subsample of the cleaned plant material was weighed into a Ni crucible. The sample was ashed at $500^{\circ} \mathrm{C}$ for 1 hour, allowed to cool in a desiccator and weighed. The ash was washed in warm, dilute hydrochloric acid, rinsed with deionized water, washed in hot $30 \%$ hydrogen peroxide, filtered through a preweighed $0.20-\mu \mathrm{m}$ filter, and rinsed thoroughly with deionized water. After drying at $55^{\circ}-60^{\circ} \mathrm{C}$, the sample was allowed to cool in a desiccator, weighed, and stored in a plastic vial. Phytolith concentration was calculated gravimetrically [Ma et al., 2001].

[14] Soil water samples were prepared by bringing soil samples to near saturation with deionized water [Lajtha et al., 1999]. After equilibrating for 72 hours, the samples were filtered through Whatman 40 filter paper and filtered again through a $0.22-\mu \mathrm{m}$ polycarbonate membrane. Sample aliquots of soil water, stream water and precipitation were analyzed for Si concentration using a blue silicomolybdous acid method and read on a spectrophotometer at $812 \mathrm{~nm}$ [Mortlock and Froelich, 1989].

\section{Plant Biogenic Si}

[15] Average plant $\mathrm{Si}$ values were calculated for aboveground biomass by assuming a $10 \%$ mean water content [Bartoli and Wilding, 1980], and a 5\% content of other elements [Drees et al., 1989], which amounts to an average plant phytolith Si content of $39.7 \%$ dry weight of the total measured plant phytolith content. Bouteloua gracilis, Buchloë dactyloides, Aristada longiseta, Carex sp., Agropyron smithii at the short grass sites ranged from $2.4 \pm$ $0.41 \%$ to $3.0 \pm 0.28 \% \mathrm{Si}$ (dry weight basis); Bouteloua gracilis, Buchloë dactyloides, Festuca sp., Poa sp. and
Schizachyrium scoparium at the mixed grass sites ranged from $2.2 \pm 0.20 \%$ to $3.6 \pm 0.47 \% \mathrm{Si}$; and Andropogon gerardii and Koeleria macrantha at the tall grass sites ranged from $1.7 \pm 0.15 \%$ to $2.1 \pm 0.17 \% \mathrm{Si}$. The widest range in values is associated with the mixed-grass sites, which also happen to have the largest range in MAP and plant species within a given grassland type. A slight though statistically nonsignificant decrease in plant $\mathrm{Si}$ (averaged across species) with increasing MAP (data not shown) was noted and may be due to differences such as plant physiology (e.g., differences in transpiration stress) or soluble $\mathrm{Si}$ in the soil. Plant Si values from the current study are in line with values for grasses (approximately 1-3\%) reported in other studies [Piperno, 1988; Epstein, 1999; Ma et al., 2001]. Species differences were noted between Bouteloua gracilis (7.5\% phytolith content) and Andropogon gerardii (2.5\% phytolith content) in a Great Plains study [Fredlund and Tieszen, 1994]. Forbs tend to accumulate less Si on a dry weight basis (with dominant forb species averaging $0.24 \pm 0.04 \% \mathrm{Si}$ for the short grass, $0.20 \pm 0.05 \%$ for the mixed grass, and $0.29 \pm 0.07 \% \mathrm{Si}$ for the tall grass sites), and a measure of just grasses would tend to overestimate $\mathrm{Si}$ stored in aboveground biomass Si. Estimates from previous LTER studies at SGS and KONZA (unpublished data from the respective LTER sites) reported a contribution of forbs to total ANPP of approximately $11 \%$ and $23 \%$, respectively. Forb silicon concentration and percentage of ANPP were factored into the aboveground biomass Si pools and litterfall $\mathrm{Si}$ flux calculations. When calculating plant $\mathrm{Si}$ on a watershed scale $\left(\mathrm{kg} \mathrm{Si} \mathrm{ha}{ }^{-1}\right)$, differences in ANPP along the bioclimosequence overshadow differences in aboveground plant Si concentration among the sites.

\section{Soil Biogenic Si}

[16] Soil phytolith data were converted to a mass/volume basis $\left(\mathrm{g} \mathrm{cm}^{-2}\right)$ by incorporating bulk density, horizon thickness, and percent soil phytolith by weight for the upper $50 \mathrm{~cm}$. Surface horizon values represent an average of three samples. These values were extrapolated to a watershed scale $\left(\mathrm{kg} \mathrm{Si} \mathrm{ha}^{-1}\right)$ assuming $10 \%$ soil phytolith water content and 5\% content of elements other than Si [Bartoli and Wilding, 1980; Bartoli, 1985; Drees et al., 1989]. To affect an equivalent comparison among all the sites, and compare the grassland data to those data reported in other ecosystems, the upper $50 \mathrm{~cm}$ of each pedon was used. This approach is reasonable, given the sharp decline in soil phytolith content with depth, but should be viewed as a minimum in cases where pedon depth exceeds $50 \mathrm{~cm}$ (Figure 3 and auxiliary material ${ }^{1}$ ).

[17] In general, the depth distributions of soil organic C and soil phytolith contents are similar and typical of plantmediated constituents, with maximum accumulation near the surface and a fairly sharp decrease with depth. However, differences between SOC and soil phytoliths in depth distribution among the different grassland systems are evident. Whereas SOC (Figure 3) and annual input of Si

\footnotetext{
${ }^{1}$ Auxiliary materials are available at ftp://ftp.agu.org/apend/gb/ 2006gb002690.
} 
soil phytolith $\left(\mathrm{g} \mathrm{cm}^{-2}\right)$

$\begin{array}{lllllll}0.0 & 0.1 & 0.2 & 0.3 & 0.4 & 0.5 & 0.6\end{array}$

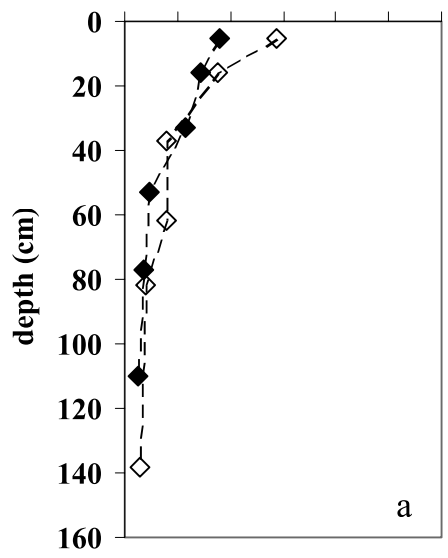

soil phytolith $\left(\mathrm{g} \mathrm{cm}^{-2}\right)$

$\begin{array}{llllllllllllllllll}0.0 & 0.1 & 0.2 & 0.3 & 0.4 & 0.5 & 0.6\end{array}$

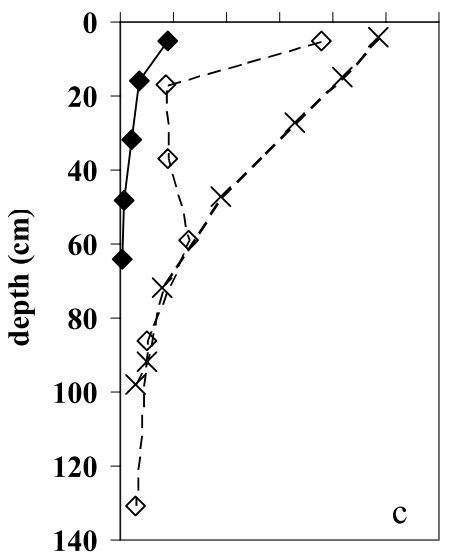

soil phytolith $\left(\mathrm{g} \mathrm{cm}^{-2}\right)$

$\begin{array}{lllllllllllll}0.0 & 0.1 & 0.2 & 0.3 & 0.4 & 0.5 & 0.6\end{array}$

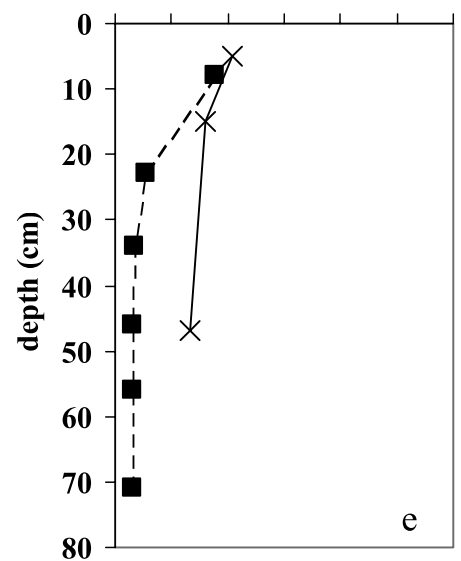

soil organic $\mathrm{C}\left(\mathrm{g} \mathrm{cm}^{-2}\right)$

$\begin{array}{lllllll}0.0 & 0.1 & 0.2 & 0.3 & 0.4 & 0.5 & 0.6\end{array}$

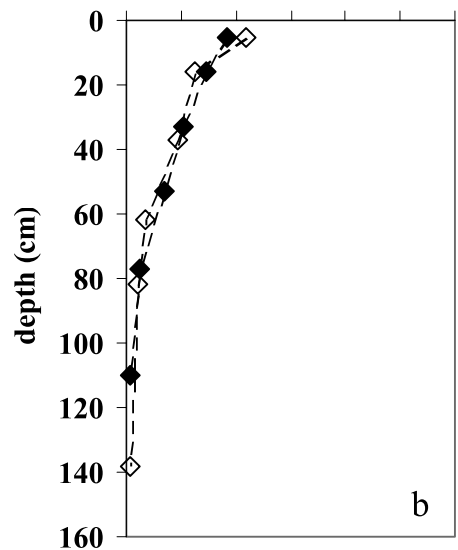

soil organic $C\left(\mathrm{~g} \mathrm{~cm}^{-2}\right)$

$\begin{array}{lllllllllllllll}0 & 0.1 & 0.2 & 0.3 & 0.4 & 0.5 & 0.6\end{array}$

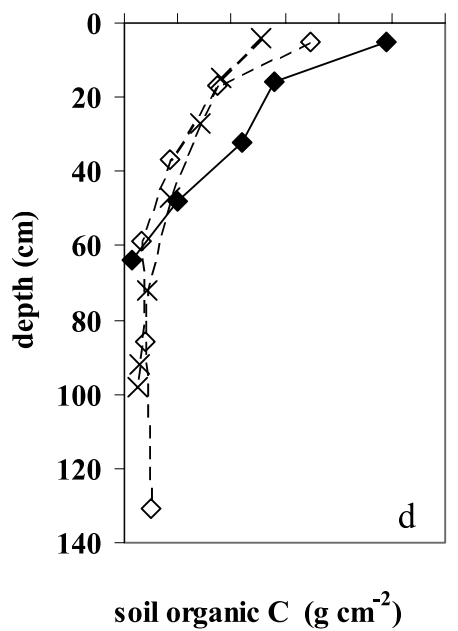

$\begin{array}{llllllllllll}0.0 & 0.1 & 0.2 & 0.3 & 0.4 & 0.5 & 0.6\end{array}$

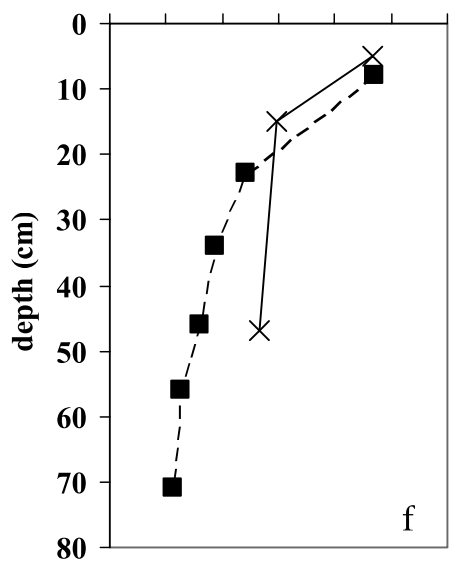

Figure 3. Soil phytolith and organic $\mathrm{C}$ depth profiles across the bioclimosequence in units of $\mathrm{g} \mathrm{cm}^{-2}$ $10 \mathrm{~cm}^{-1}$. (a, b) Short grass sites: solid symbols represent SGS and open symbols represent Arikaree. (c, d) Mixed grass sites: solid symbols represent Wilson, open symbols represent Hays, and crosses represent SV. (e, f) Tall grass sites: solid symbols represent Konza and open symbols represent WahKon-Tah. 
Table 2. Silicon Distribution in Terms of Pools and Fluxes Across the Bioclimosequence ${ }^{\mathrm{a}}$

\begin{tabular}{|c|c|c|c|c|c|c|c|}
\hline & SGS & Arik & Smokey Valley & Hays & Wilson & Konza & WKT \\
\hline \multicolumn{8}{|c|}{ Pools, $k g \mathrm{Si} \mathrm{ha} a^{-1}$} \\
\hline Aboveground biomass & $26 \pm 9$ & $22 \pm 16$ & $56 \pm 28$ & $58 \pm 25$ & $55 \pm 8$ & $67 \pm 16$ & $59 \pm 8$ \\
\hline Soil phytoliths $\left(\times 10^{3}\right)$ & $32 \pm 2.6$ & $31 \pm 1.8$ & $67 \pm 2.9$ & $30 \pm 2.4$ & $8 \pm 0.4$ & $18 \pm 2.2$ & $20 \pm 1.7$ \\
\hline $\begin{array}{l}\text { Soil Minerals }\left(\times 10^{6}\right) 2 \mu \mathrm{m} \\
\quad \text { to } 2 \mathrm{~mm}\end{array}$ & $1.76 \pm 0.25$ & $1.92 \pm 0.35$ & $1.53 \pm 0.25$ & $1.48 \pm 0.35$ & $1.29 \pm 0.15$ & $1.39 \pm 0.35$ & $1.94 \pm 0.35$ \\
\hline Soil Minerals $\left(\times 10^{6}\right)<2 \mu \mathrm{m}$ & $0.31 \pm 0.05$ & $0.28 \pm 0.05$ & $0.34 \pm 0.05$ & $0.40 \pm 0.05$ & $0.49 \pm 0.05$ & $0.56 \pm 0.10$ & $0.23 \pm 0.05$ \\
\hline \multicolumn{8}{|c|}{ Fluxes, $k g S i h a^{-1} y r^{-1}$} \\
\hline Atmospheric input & $2 \pm 1$ & $2 \pm 1$ & $2 \pm 1$ & $2 \pm 1$ & $2 \pm 1$ & $2 \pm 1$ & $2 \pm 1$ \\
\hline Litterfall & $26 \pm 9$ & $22 \pm 16$ & $56 \pm 28$ & $58 \pm 25$ & $55 \pm 8$ & $67 \pm 16$ & $59 \pm 8$ \\
\hline Labile phytoliths & $17 \pm 6$ & $16 \pm 10$ & $43 \pm 26$ & $46 \pm 20$ & $51 \pm 8$ & $57 \pm 14$ & $43 \pm 6$ \\
\hline Stable phytoliths & $9 \pm 4$ & $6 \pm 4$ & $13 \pm 8$ & $12 \pm 5$ & $4 \pm 1$ & $10 \pm 2$ & $16 \pm 3$ \\
\hline Stream/ground water & $0.2 \pm 0.03$ & $0.5 \pm 0.03$ & $0.3 \pm 0.05$ & $1.5 \pm 0.40$ & $1.7 \pm 0.48$ & $6.3 \pm 2.7$ & $11.0 \pm 3.8$ \\
\hline
\end{tabular}

${ }^{\mathrm{a}}$ Errors listed represent \pm 1 standard error of the mean. Aboveground biomass $=$ litterfall $=\mathrm{ANPP}=\mathrm{ANPP}(\mathrm{kg} / \mathrm{ha}) \times$ average Si content $(\%)$ of dominant grasses and forbs. The relatively large errors associated with these components are due to the variability associated with ANPP measurements as taken from McCulley and Burke [2004], and are carried through to the other flux calculations. Soil phytoliths = horizon depth $(\mathrm{cm}) \times$ bulk density $\left(\mathrm{g} \mathrm{cm}^{-3}\right) \times$ soil phytolith Si content $(\%)$. Soil minerals $=$ horizon depth $(\mathrm{cm}) \times$ bulk density $\left(\mathrm{g} \mathrm{cm}^{-3}\right) \times$ soil mineral Si content $(\%)$. Soil phytolith and soil mineral $\mathrm{Si}$ are calculated for the top $50 \mathrm{~cm}$. See text for estimations of atmospheric input, stable and labile phytoliths and stream/groundwater. Here n.d. denotes not determined. Data and additional details for calculations are available in Table 1, the text, or auxiliary material.

though litterfall (Table 2) increase with increasing precipitation (i.e., from short to tall grass), soil phytoliths show the opposite trend, despite increases in Si inputs via plant cycling (Table 2). Assuming phytolith solubility among the grasses is similar, the interaction between weathering intensity and litterfall inputs presents a likely explanation. Short grass systems experience the lowest weathering intensity along the bioclimatic gradient and receive the least amount of annual plant $\mathrm{Si}$; whereas the relatively large annual inputs of plant $\mathrm{Si}$ associated with tall grass systems may be offset by greater weathering intensity. The large variability of soil phytolith content within the mixed grass sites may be due to differences among plant communities and parent material. The Wilson site, though falling within the mixed grass zone geographically, more closely resembles a tall grass site in terms of species composition, SOC and soil phytolith pools. The low soil phytolith content may also reflect parent material composition, as the soil at this site is fairly shallow to limestone, and higher $\mathrm{pH}$ generally increases phytolith solubility [Fraysse et al., 2004].

[18] Soils contain roughly 10,000 times more biogenic $\mathrm{Si}$ than the aboveground biomass when viewing these grassland systems as a whole (Table 2). On a watershed scale, the greatest stores of soil phytoliths on average are found in the mixed grass sites $\left(48,500 \mathrm{~kg} \mathrm{Si} \mathrm{ha}^{-1} ; 1.8 \%\right.$ of total soil $\left.\mathrm{Si}\right)$, followed by short grass $(31,500 \mathrm{~kg} \mathrm{Si} / \mathrm{ha} ; 1.5 \%$ of total soil $\mathrm{Si})$ and tall grass sites $\left(15,300 \mathrm{~kg} \mathrm{Si} \mathrm{ha}^{-1} ; 0.9 \%\right.$ of total soil Si). As mentioned previously, soil biogenic $\mathrm{Si}$ is a small portion of the total Si pool, but likely undergoes faster turnover than the larger more stable pool of mineral derived Si [Alexandre et al., 1997]. Annual variability in ANPP suggests that biogenic Si cycling (like $\mathrm{C}$ cycling in these systems) may be tightly linked to water availability and show significant variability from year to year.

\section{Soil Mineral Si}

[19] Soil mineral Si was split into two size fractions: $<2 \mu \mathrm{m}$ (clay) and $2 \mu \mathrm{m}-2 \mathrm{~mm}$ (silt and sand). From X-ray diffraction analysis (data not shown), quartz and feldspar were found to dominate the sand and silt size fraction, with smectite, illite and kaolinite comprising the majority of the clay fraction. Increasing clay content (clay $=0.0029$ (MAP) $+0.705, \mathrm{r}^{2}=0.872$; excluding the WKT site, which has a much lower clay content due to the more resistant sandstone parent material), and decreasing carbonate content (carbonate $=12.952 \mathrm{e}^{-0.0127(\mathrm{MAP})}, \mathrm{r}^{2}=0.952$; excluding the Wilson site, which formed in relatively shallow limestone) along the bioclimosequence reveal typical trends in these parameters. Differences in mineral Si among the study sites are a reflection of climate and parent material, with slightly more total soil Si found in more resistant parent materials (e.g., ARIK and WKT). Not surprising, mineral Si dominates the overall Si pool in the soil, comprising from 96 to $99 \%$ of the total soil Si across the bioclimosequence (Table 2).

[20] Minor decreases in soil $\mathrm{Si}$ and $\mathrm{Al}$ relative to the parent material (data not shown) were observed throughout the bioclimosequence and are indicative of the minimal weathering associated in these semiarid ecosystems. However, atmospheric input cannot be ruled out as a partial explanation for maintaining an elemental balance relative to the parent material (i.e., it is difficult to quantify the impact of eolian additions versus weathering losses and flux). Surficial losses of $\mathrm{Al}$ across the weathering gradient provide another potential line of evidence of weathering and illuvial transport in these systems. Greater surficial losses of $\mathrm{Al}$ compared to $\mathrm{Si}$ across the bioclimosequence may be the result of greater Si biocycling supporting higher surficial $\mathrm{Si}$ concentration.

\section{External Inputs and Outputs}

[21] To determine the impact of atmospheric Si inputs to these systems, Si concentrations were directly measured via precipitation or estimated in the case of dust deposition. Monthly rainfall samples taken from April through September 2003 near the SGS sites were analyzed for Si concentration, averaging $0.01 \mathrm{mg} \mathrm{Si} \mathrm{L}^{-1}$ (s.e. $\pm 0.003 \mathrm{mg} \mathrm{Si} \mathrm{L}^{-1}$ ), or approximately $0.03 \mathrm{~kg} \mathrm{Si} \mathrm{ha}{ }^{-1} \mathrm{yr}^{-1}$ over the period studied. Applying this concentration across the study gra- 
dient, the maximum amount of $\mathrm{Si}$ added to the wettest site (WKT) would be approximately $0.1 \mathrm{~kg} \mathrm{Si} \mathrm{ha}^{-1} \mathrm{yr}^{-1}$. An estimate of annual dust influx rates and the $\mathrm{Si}$ concentration of that dust were used to calculate eolian Si inputs. Dust deposition rates in the Central Great Plains have been estimated at approximately 2 to $10 \mathrm{~kg} \mathrm{ha}^{-1} \mathrm{yr}^{-1}$ [Mahowald et al., 1999], a range that spans the last glacial maximum (approximately $18 \mathrm{ky}$ ) to the present. Combining the average of this influx rate with a typical Great Plains loess composition of $20 \%$ clay and $80 \%$ silt [Roberts et al., 2003 ], and an average $\mathrm{SiO} 2$ concentration of $33 \%$ for clay and $77 \%$ for silt as measured from surface horizons of the current study, we calculated an average annual dry deposition rate of approximately $2 \mathrm{~kg} \mathrm{Si} \mathrm{ha}^{-1} \mathrm{yr}^{-1}$.

[22] Given the minor input of precipitation derived $\mathrm{Si}$, this component was omitted from the total atmospheric input estimates, which were based solely on the dust input estimation of $2 \mathrm{~kg} \mathrm{Si} \mathrm{ha}{ }^{-1} \mathrm{yr}^{-1}$. In previous studies of terrestrial Si cycling, atmospheric inputs were estimated at $<1$ to $1.5 \mathrm{~kg} \mathrm{Si} \mathrm{ha}{ }^{-1} \mathrm{yr}^{-1}$ (Alexandre et al. [1997] and Bartoli [1983], respectively], and either omitted or comprised a very small portion of the overall $\mathrm{Si}$ cycle. The slightly higher values estimated for this study seem reasonable given the drier climate associated with grassland systems compared to forests and would be strengthened by direct measurements in future studies. However, estimation errors are likely to have a minor impact, as this input is a minor component in the terrestrial biogeochemical $\mathrm{Si}$ cycle, representing $<10 \%$ of the plant-derived $\mathrm{Si}$ inputs on an annual basis (Table 2).

[23] As phytolith inputs are influenced by ANPP in grasslands, the primary ecological determinants of ANPP in these ecosystems (climate, grazing and fire [Knapp et al., 1998] are all likely to be important. In particular, the inputs and outputs of phytolith by fire and grazing is understudied but likely critical. Fire, in addition to affecting ANPP may be most important as a direct vector of $\mathrm{Si}$ loss from ecosystems where fire frequency is higher due to the loss of Si rich ash after fire, and grazing may have the opposite effect in that grasses increase $\mathrm{Si}$ concentration with heavy grazing [McNaughton et al., 1985] and foliage consumption will speed the cycling of Si rich plant materials back into the soil pool through decomposition.

[24] Average monthly discharge, stream Si concentration and watershed area were used to calculate an average annual $\mathrm{Si}$ discharge in $\mathrm{kg} \mathrm{Si} \mathrm{ha}^{-1} \mathrm{yr}^{-1}$. Silica stream water concentrations of $\mathrm{Si}$ decreased slightly across the bioclimatic gradient, short grass sites: $10.3 \pm 0.48 \mathrm{mg} \mathrm{Si} \mathrm{L}^{-1}, \mathrm{n}=3$ watersheds; mixed grass sites: $8.5 \pm 0.35 \mathrm{mg} \mathrm{Si} \mathrm{L}^{-1}, \mathrm{n}=2$ watersheds; tall grass sites: $5.1 \pm 0.33 \mathrm{mg} \mathrm{Si} \mathrm{L}^{-1}, \mathrm{n}=5$ watersheds). However, greater stream discharge associated with wetter sites led to substantial increases in $\mathrm{Si}$ output along the gradient $\left(\mathrm{Si}\right.$ export $=0.0149$ (MAP) $-6.569 ; \mathrm{r}^{2}=$ 0.935; Table 2). Groundwater exports of $\mathrm{Si}$ are assumed to be minor and accounted for by stream water measurements.

\section{Phytolith Solubility and Turnover}

[25] Plant type and chemical composition tend to drive differences in phytolith solubility. Phytoliths of grass and deciduous species tend to be more soluble than those of conifers due to differences in $\mathrm{Si} / \mathrm{Al}$ ratios, surface are and water content [Bartoli and Wilding, 1980; Bartoli, 1985]. Bamboo phytolith dissolution rates were found to fall between quartz and vitreous silica with a positive linear increase relative to $\mathrm{pH}$ [Fraysse et al., 2004]. Phytoliths isolated from soils tend to have greater $\mathrm{Al}$ concentration, less water and surface area and consequently are less soluble than those extracted from plants [Bartoli and Wilding, 1980].

[26] Different approaches of varying complexity have been used to estimate the annual input of biogenic $\mathrm{Si}$ to the soluble Si pool through phytolith dissolution. Biogenic silica mean residence time and soil profile distribution of phytoliths have been used to estimate phytolith solubility in temperate forests [Bartoli, 1983]. Phytolith solubility has also been estimated by radiocarbon dating annual plant phytolith inputs and the total soil phytolith pool [Meunier et al., 1999]. Soil phytoliths behave in a manner similar to soil organic carbon, with a labile pool that decreases rapidly with depth and a more stable pool of less soluble phytoliths that maintain a relatively constant concentration throughout the profile [Alexandre et al., 1997].

[27] In the current study, the relationship between soil organic carbon and soil phytoliths varies by grassland type (Figure 3). In general, phytoliths tend to accumulate in the soil to a greater extent than SOC in the drier sites (i.e., short and mixed grass, where MAP $<600 \mathrm{~mm}$ ). Soil organic carbon accumulates to a greater extent at the wetter sites (i.e., tall grass where MAP $>600 \mathrm{~mm}$ ). Such a distribution illustrates that both translocation and dissolution of the soil phytoliths are likely occurring in the soil as evidenced in other ecosystems [Alexandre et al., 1997]. If translocation were the only process, the annual influx and soil phytolith pool would provide an estimate of the soil age of approximately $10^{2}-10^{3}$ years across the bioclimosequence of the current study. Radiocarbon dates [Blecker et al., 1997], soil morphology and geomorphic evidence [Oviatt, 1998] across the bioclimosequence imply that phytolith dissolution has occurred, as this age range is too young for these soils.

[28] Mean residence time or turnover of soil phytoliths is key to calculating phytolith dissolution. Degree of pitting and presence of different phytolith types in plants and litter have been used to estimate a mean residence time of $6-$ 18 months for phytoliths in the litter of tropical forests [Alexandre et al., 1994]. Phytolith turnover rates of temperate forest systems have been estimated in plants $(0.5$ to 2.4 years), litter (2 to 10 years), and soil (1 to 300 years) [Bartoli and Souchier, 1978], with coniferous forests having slower turnover times than deciduous forests. Using the ratio of soil phytolith pool $\left(\mathrm{kg} \mathrm{Si} \mathrm{ha}^{-1}\right) /$ annual litterfall $\mathrm{Si}$ input $\left(\mathrm{kg} \mathrm{Si} \mathrm{ha}{ }^{-1} \mathrm{yr}^{-1}\right)$, we estimated turnover times for soil phytoliths across the bioclimosequence, finding a relatively strong trend of faster turnover with increasing MAP. Turnover rates for soil phytoliths at the short grass sites average $1300 \pm 800$ years, mixed grass sites average $850 \pm 500$ years, and tall grass sites $250 \pm$ 70 years. As water availability increases, so do plant production and phytolith dissolution, ultimately leading to smaller pools and faster turnover rates. 
[29] We estimated Si flux from phytolith dissolution based on a bicompartmental distribution [Alexandre et al., 1997], that assumes soils are in equilibrium with the current vegetation, and that surface horizon soil phytoliths represent the phytolith input from the litter to the soil before translocation and dissolution. The lowest two horizons for the drier sites (SGS, Arikaree, Smokey Valley, Hays) and lowest horizon for the wetter sites (Wilson, Konza, WKT) were chosen to represent the stable phytolith fraction, based on pedon depth and phytolith distribution. The stable pool was then compared to the surface horizon, which is assumed to contain both labile and stable phytolith pools (Table 2). The labile phytolith pool tends to increase across the bioclimatic gradient, with short, mixed and tall grass sites averaging $69 \%, 83 \%$, and $79 \%$ of the litterfall pools, respectively, compared to a $92 \%$ labile phytolith pool in the tropical forest system [Alexandre et al., 1997].

\section{Comparison Between Grasslands and Forest: Phytolith Distribution and Behavior}

[30] Additions of biogenic Si to soil are primarily driven by plant Si concentration, ANPP, and litterfall. In general, greater total ANPP and aboveground Si storage in forest systems are offset by the greater annual litterfall associated with grassland systems, which are near 100\% compared to approximately $5-10 \%$ for forests [Bartoli, 1983; Lucas et al., 1993]. Tropical forests and mixed tall grass systems are quite similar in terms of annual biogenic $\mathrm{Si}$ inputs to the soil, the former having a range of 41-67 kg Si ha ${ }^{-1} \mathrm{yr}^{-1}$ [Lucas et al., 1993, Alexandre et al., 1997] and the latter $55-67 \mathrm{~kg} \mathrm{Si} \mathrm{ha}^{-1} \mathrm{yr}^{-1}$ (this study). Annual litterfall Si inputs from the deciduous forest site $\left(22 \mathrm{~kg} \mathrm{Si} \mathrm{ha}^{-1} \mathrm{yr}^{-1}\right.$ [Bartoli, 1983]) are comparable to the short grass systems $\left(22-26 \mathrm{~kg} \mathrm{Si} \mathrm{ha}^{-1} \mathrm{yr}^{-1}\right)$, and greater than annual Si additions associated with the coniferous forest $(4.5 \mathrm{~kg} \mathrm{Si}$ $\mathrm{ha}^{-1} \mathrm{yr}^{-1}$ [Bartoli, 1983]).

[31] Despite vast differences in ecosystem parameters such as MAP, ANPP, and parent material between the forests and grasslands examined thus far, stores of soil phytoliths in these systems are remarkably similar. Though representing only one tropical forest site, the soil phytolith pools in the upper $50 \mathrm{~cm}$ of that system $\left(19 \times 10^{3} \mathrm{~kg} \mathrm{Si} \mathrm{ha}^{-1}\right.$ for Alexandre et al. [1997]) is comparable to those of the grasslands measured in this study (Table 2). The deciduous $\left(0.45 \times 10^{3} \mathrm{~kg} \mathrm{Si} \mathrm{ha}^{-1}\right)$ and coniferous $\left(1.4 \times 10^{3} \mathrm{~kg} \mathrm{Si} \mathrm{ha}^{-1}\right)$ forest soil phytolith pools are roughly an order of magnitude less [Bartoli, 1983], reflecting the lower plant Si concentration, lower litterfall inputs and possibly greater weathering intensity compared to the grasslands. However, differences in phytolith solubility among the plant species, as discussed earlier, present another explanation. Given the relative similarities in soil biogenic Si distribution between grasslands and forests, a discussion of phytolith impact on mineral weathering follows.

\section{Phytolith Impact on Mineral Weathering}

[32] Researchers have long recognized that plants can increase chemical weathering rates in soils by root exudates, cation biocycling, altering soil physical properties that impact mineral/water interaction time, and biogenic mineral production [Lovering, 1959; Berner, 1992; Drever, 1994; Kelly et al., 1998]. Table 3 (populated by data from Table 2) presents a closer look at the impact of plants on mineral weathering in terms of potential mineral dissolution (in units of $\mathrm{kg} \mathrm{Si} \mathrm{ha}^{-1} \mathrm{yr}^{-1}$ ) along the grassland bioclimosequence of the current study, compared to forested ecosystems from previous studies. The input-output mass balance approach (first data column in Table 3 ) is a relatively simple means of estimating the relative degree of weathering in a system, the difference between the two accounting for element accrual or loss. A net ecosystem loss in Si occurs when the $\mathrm{Si}$ output (stream water Si concentrations) exceed $\mathrm{Si}$ inputs (atmospheric dust deposition). Applied to the current study, this relationship shows the expected impact of climate on weathering; where mineral dissolution $=-0.0149$ (MAP) + 8.5688; $\mathrm{r}^{2}=0.932$. Net export of Si from watersheds does not occur until effective moisture is great enough to support tall grass ecosystems when Si lost to stream water (assuming that groundwater $\mathrm{Si}$ ultimately winds up in streams) exceeds eolian $\mathrm{Si}$ inputs. Si exports from tall grass ecosystems approach those found in forested ecosystems (Table 3).

[33] Comparing elemental inputs and outputs typically excludes information about internal cy cling of elements and the impact of biogenic cycling on weathering. When plant cycling of $\mathrm{Si}$ is included, the impact on mineral dissolution is potentially much greater, as indicated by the calculated increase in $\mathrm{Si}$ released by mineral dissolution (second data column in Table 3). As the annual dissolution of soil phytoliths is not sufficient to meet the annual plant uptake of $\mathrm{Si}$, additional $\mathrm{Si}$ (assuming the inputs and outputs are relatively constant over time) would be supplied from mineral dissolution. Although not as strong as the inputoutput trend, there is a noticeable positive relationship along the weathering gradient (mineral dissolution = -0.017 (MAP) $-3.484 ; \mathrm{r}^{2}=0.493$ ), where internal plant cycling increases the amount of Si released through mineral dissolution. A threshold of plant $\mathrm{Si}$ concentration and ANPP may exist that helps explain the similarity in mixed and tall grass systems and their greater impact on mineral dissolution over short grass sites.

[34] Even though overall weathering appears greater in forested ecosystems (as seen in the greater stream outputs of dissolved $\mathrm{Si}$ ), the impact of plant Si cycling on mineral weathering in grasslands is on the same order of magnitude. Grasses tend to accumulate more Si on a dry weight basis and turnover just as much $\mathrm{Si}$, if not more, on an annual basis, offsetting the greater overall ANPP seen in forested systems.

[35] The third data column in Table 3 further refines the impact of plant Si cycling by removing the input and output fluxes. The impact of grassland systems on mineral dissolution changes slightly, with mixed grass $>$ tall grass $>$ short grass. Though limited in number, a comparison between ecosystems reveals that grasslands have a twofold increase on mineral dissolution over forests (grassland average: $-12.7 \mathrm{~kg} \mathrm{Si} \mathrm{ha}^{-1} \mathrm{yr}^{-1}(\mathrm{n}=7)$; forests average: $-6.5 \mathrm{~kg}$ $\left.\mathrm{Si} \mathrm{ha}^{-1} \mathrm{yr}^{-1}(\mathrm{n}=4)\right)$. This result suggests that Si biocycling 
Table 3. Comparison of the Impact of Si Biocycling on Mineral Dissolution of Si Between Grassland and Forest Ecosystems on an Annual Basis ${ }^{\mathrm{a}}$

\begin{tabular}{|c|c|c|c|}
\hline & \multicolumn{3}{|c|}{ Mineral Dissolution, $\mathrm{kg} \mathrm{Si} \mathrm{ha}^{-1} \mathrm{yr}^{-1}$} \\
\hline & $\begin{array}{c}\text { Without Plant Si Cycling } \\
\text { (Inputs-Outputs) }\end{array}$ & $\begin{array}{c}\text { With Plant Si Cycling } \\
\text { (Input + Phytolith Dissolution) } \\
- \text { (Output + Plant Uptake) }\end{array}$ & $\begin{array}{c}\text { Phytolith Dissolution } \\
\text { - Plant Uptake } \\
\end{array}$ \\
\hline \multicolumn{4}{|l|}{ Grasslands } \\
\hline SGS (short grass) & $1.8 \pm 1.2$ & $-7.2 \pm 6$ & $-9 \pm 6$ \\
\hline ARIK (short grass) & $1.5 \pm 0.8$ & $-4.5 \pm 4$ & $-6 \pm 5$ \\
\hline SV (mixed grass) & $1.7 \pm 1.1$ & $-11.3 \pm 10$ & $-13 \pm 12$ \\
\hline HAYS (mixed grass) & $0.5 \pm 0.3$ & $-11.5 \pm 10$ & $-12 \pm 10$ \\
\hline WILSON (mixed grass) & $0.3 \pm 0.2$ & $-3.7 \pm 3$ & $-4 \pm 1$ \\
\hline KONZA (tall grass) & $-4.3 \pm 3.6$ & $-14.3 \pm 11$ & $-10 \pm 5$ \\
\hline WKT (tall grass) & $-9.0 \pm 7.6$ & $-25.0 \pm 14$ & $-16 \pm 4$ \\
\hline \multicolumn{4}{|l|}{ Forests } \\
\hline Mixed deciduous/coniferous ${ }^{b}$ & -10.5 & n.d. & n.d. \\
\hline Coniferous $^{\mathrm{b}}$ & -5.5 & n.d. & n.d. \\
\hline Deciduous $^{\mathrm{c}}$ & n.d & n.d. & -6.0 \\
\hline Coniferous $^{\mathrm{c}}$ & -24.5 & -28.5 & -1.0 \\
\hline Tropical-Congo $^{\mathrm{d}}$ & -15.0 & -20.0 & -5.0 \\
\hline Tropical-Amazon $^{\mathrm{e}}$ & -11.0 & n.d. & n.d. \\
\hline
\end{tabular}

${ }^{\text {a }}$ Positive values represent a net increase in $\mathrm{Si}$; however this is not to imply that mineral weathering is not occurring. Negative values represent a hypothesized increase in mineral dissolution. (Inputs $=$ atmospheric deposition; outputs $=$ stream $/$ groundwater export; phytolith dissolution $=\mathrm{Si}$ addition through dissolution of labile phytoliths; plant uptake $=\mathrm{Si}$ uptake stored in aboveground biomass). Errors listed represent \pm 1 standard error of the mean. Here. n.d. denotes not determined due to insufficient data.

${ }^{\mathrm{b}}$ Bartoli and Souchier [1978].

${ }^{\mathrm{c} B a r t o l i}$ [1983].

${ }^{\mathrm{d}}$ Alexandre et al. [1997].

${ }^{\mathrm{e}}$ Lucas et al. [1993], assuming negligible atmospheric input.

may influence mineral weathering to a greater extent in grasslands compared to forests, where climate driven weathering overshadows weathering associated with Si biocycling.

[36] A key Si pathway not included in this calculation is secondary mineral formation (Figure 1). This pathway would further deplete the stock of soluble Si available for plant uptake, theoretically increasing the amount of $\mathrm{Si}$ released through primary mineral dissolution in order to maintain the calculated rates of plant Si uptake. As weathering intensity and thus clay formation should increase along the bioclimosequence, this impact would be greater along the bioclimosequence as well.

\section{Conclusions}

[37] Phytolith distribution in grasslands is similar to that of soil organic carbon and is driven largely by ANPP and the influence of water availability on weathering intensity. Across a grassland bioclimosequence in the Great Plains, soil phytolith pools tend to decrease with increasing MAP, even though annual phytolith inputs through litterfall (ANPP) increase. From the perspective of an ecosystem scale Si mass balance, biogenic Si cycling should enhance mineral dissolution, as phytolith dissolution alone is not sufficient to meet annual plant Si uptake. Comprising 1$3 \%$ of the total Si pool, this more soluble pool of biogenic Si likely has a direct impact on Si flux to both soil solution and streams. On a watershed scale, Si biocycling is comparable between forests and grasslands and since grasslands cover about $40 \%$ of terrestrial Earth [White et al.,
2000], they likely play an important role in the global Si cycle.

\section{Potential Significance of Grasslands in Global Si Biogeochemistry}

[38] Conley, 2002 estimated global Si storage in aboveground biomass at 60-200 Tmol Si (on the basis of an average and global annual $\mathrm{C}$ production of $60 \mathrm{Pg} \mathrm{C} \mathrm{yr}^{-1}$ and a molar Si:C ratio of 0.012 to 0.040 ). Our estimates for aboveground biomass in North American nonwoody grasslands $\left(1,220,000 \mathrm{~km}^{2}\right.$ [White et al., 2000]), arrived at by scaling up the ANPP and plant Si data from this study, are approximately $0.3 \mathrm{Tmol} \mathrm{Si}$. Of greater interest however is the belowground store of biogenic $\mathrm{Si}$, which comprises roughly $130 \mathrm{Tmol}$ of Si. Measurements of other grassland systems (savannah, shrubland, and tundra, which comprise an additional $9,520,000 \mathrm{~km}^{2}$ [White et al., 2000] would further refine the role of grasslands in the global biogeochemical $\mathrm{Si}$ cycle and the concomitant rise of grasslands and diatomaceous marine deposits associated with the late Miocene [Kidder and Gierlowski-Kordesch, 2005].

[39] Acknowledgments. This material is based upon work supported by the National Science Foundation under grant DEB 0217631 and funding from the Colorado Agricultural Experiment Station.

\section{References}

Alexandre, A., F. Colin, and J. D. Meunier (1994), Les phytolithes, indicateurs du cycle biogeochimique du silicium en foret equatoriale, $C . R$. Acad. Sci., Ser. II, 319, 453-458. 
Alexandre, A., J. D. Meunier, F. Colin, and J. M. Koud (1997), Plant impact on the biogeochemical cycle of silicon and related weathering processes, Geochim. Cosmochim. Acta, 61, 677-682.

Axelrod, D. I. (1985), Rise of the grassland biome, Central North America, Bot. Rev., 51, 163-201.

Bartoli, F. (1983), The biogeochemical cycle of silica in two temperate forest ecosystems, Environ. Biogeochem. Ecol. Bull., 35, 469-476.

Bartoli, F. (1985), Crystallochemistry and surface properties of biogenic opal, J. Soil Sci., 36, 335-350.

Bartoli, F., and B. Souchier (1978), Cycle et role du silicium d'origine vegetale dans les ecosystems forestiers temperes, Ann. Sci. For., 78, $187-202$.

Bartoli, F., and L. P. Wilding (1980), Dissolution of biogenic opal as a function of its physical and chemical properties, Soil Sci. Soc. Am. J., 44, 873-878

Berner, R. A. (1992), Weathering, plants and the long-term carbon cycle, Geochim. Cosmochim. Acta, 56, 3225-3231.

Berner, R. A. (1995), Chemical weathering and its effect on atmospheric $\mathrm{CO}_{2}$ and climate, in Chemical Weathering of the Silicate Minerals, Rev. Miner., vol. 31, edited by A. F. White, and S. L. Brantley, pp. 565-583, Am. Miner. Soc., Washington, D. C.

Blake, G. R., and K. H. Hartge (1986), Bulk density, in Methods of Soil Analysis: Part 1, Agron. Monogr., vol. 9, 2nd ed., edited by A. Klute, p. 363-375, Am. Soc. of Agron., Madison, Wis.

Blecker, S. W., C. M. Yonker, C. G. Olson, and E. F. Kelly (1997), Paleopedologic and geomorphic evidence for Holocene climate variation, shortgrass steppe, Colorado, USA, Geoderma, 76, 113-130.

Blinnikov, M., A. Busacca, and C. Whitlock (2002), Reconstruction of the late Pleistocene grassland of the Columbia basin, Washington, USA, based on phytolith records in loess, Palaeogeogr. Palaeoclimatol. Palaeoecol., 177, 77-101.

Chadwick, O. A., E. F. Kelly, D. M. Merritts, and R. G. Amundson (1994), Carbon dioxide consumption during soil development, Biogeochemistry, 24, $115-127$

Conley, D. J. (2002), Terrestrial ecosystems and the global biogeochemical silica cycle, Global Biogeochem. Cycles, 16(4), 1121, doi:10.1029/ 2002GB001894.

Dahlgren, R. A., S. Shoji, and M. Nanzyo (1993), Mineralogical characteristics of volcanic ash soils, in Volcanic Ash Soils, Genesis, Properties and Utilization, edited by S. Shoji et al., pp. 101-145, Elsevier, New York.

Derry, L. A., A. C. Kurtz, K. Ziegler, and O. A. Chadwick (2005), Biological control of terrestrial silica cycling and export fluxes to watersheds, Nature, 433, $728-731$

Drees, L. R., L. P. Wilding, N. E. Smeck, and A. L. Senkayi (1989), Silica in soils: Quartz and disordered silica polymorphs, in Minerals in Soils Environments, edited by J. B. Dixon and S. B. Weed, pp. 913-974, Soil Sci. Soc. of Am., Madison Wis.

Drever, J. I. (1994), Effect of plants on chemical weathering rates, Geochim. Cosmochim. Acta, 58, 2325-2332.

Epstein, E. (1994), The anomaly of silicon in plant biology, Proc. Natl. Acad. Sci. U. S. A., 91, 11-17.

Epstein, E. (1999), Silicon, Annu. Rev. Plant Physiol. Plant Mol. Biol., 50, $641-664$.

Farmer, V. C., E. Delbos, and J. D. Miller (2005), The role of phytolith formation and dissolution in controlling concentrations of silica in soil solutions and streams, Geoderma, 127, 71-79.

Fraysse, F., O. S. Pokrovski, J. Schott, and J. D. Meunier (2004), Surface properties, solubility and dissolution kinetics of phytoliths, from bamboos of Reunion Island, paper presented at Goldschmidt 2004, Geol Inst., Univ. of Copenhagen, Copenhagen.

Fredlund, G. G., and L. L. Tieszen (1994), Modern phytolith assemblages from the North American Great Plains, J. Biogeogr., 21, 321-335.

Gaillardet, J., B. Dupre, P. Louvat, and C. J. Allegre (1999), Global silicate weathering and $\mathrm{CO}_{2}$ consumption rates deduced from the chemistry of large rivers, Chem. Geol., 159, 3-30.

Gee, G. W., and J. W. Bauder (1986), Particle-size analysis, in Methods of Soil Analysis: Part 1, Agron. Monogr., vol. 9, 2nd ed., edited by A. Klute, p. $383-411$, Am. Soc. of Agron., Madison, Wis.

Jenny, H. (1941), Factors of Soil Formation; A System of Quantitative Pedology, 281 pp., McGraw-Hill, New York.

Jones, L. H. P., and K. A. Handreck (1967), Silica in soils, plants and animals, Adv. Agron., 19, 107-149.

Kelly, E.F. (1989), A study of the influence of climate and vegetation on the stable isotope chemistry of soils in grassland ecosystems of the Great Plains, Ph. D. dissertation, 142 pp., Colorado State Univ., Fort Collins.

Kelly, E.F. (1990), Methods for extracting opal phytoliths from soil and plant material, report, Dep. of Agron., Colorado State Univ., Fort Collins.
Kelly, E. F., R. G. Amundson, B. D. Marino, and M. J. DeNiro (1991), The stable isotope ratio of carbon in phytoliths as a quantitative method of monitoring vegetation and climatic change, Quat. Res., 35, 222-233.

Kelly, E. F., B. D. Marino, and C. M. Yonker (1993), Stable carbon isotope composition of paleosols: An application to the Holocene, in Climate Change in Continental Isotopic Records, Geophys. Monogr. Ser, vol. 78, edited by P. K. Swart et al., pp. 233-239, AGU, Washington, D. C.

Kelly, E. F., O. A. Chadwick, and T. E. Hilinski (1998), The effect of plants on mineral weathering, Biogeochemistry, 42, 21-53.

Kidder, D. L., and E. H. Gierlowski-Kordesch (2005), Impact of grassland radiation on nonmarine silica cycle and Micoene diatomite, Palaios, 20, $198-206$.

Knapp, A. K., J. M. Briggs, J. M. Blair, and C. L. Turner (1998), Patterns and controls of aboveground net primary production in tallgrass prairie, in Grassland Dynamics: Long-Term Ecological Research in Tallgrass Prairie, edited by A. K. Knapp et al., pp. 193-221, Oxford Univ. Press, New York.

Lajtha, K., W. M. Jarrell, D. W. Johnson, and P. Sollins (1999), Collection of soil solution, in Standard Soil Methods for Long-Term Ecological Research, edited by G. P. Robertson et al., pp. 166-182, Oxford Univ. Press, New York.

Lindsay, W. L. (1979), Chemical Equilibria in Soils, 449 pp., John Wiley, Hoboken, N. J.

Lovering, T. S. (1959), Significance of accumulator plants in rock weathering, Bull. Geol. Soc. Am., 70, 781-800.

Lucas, Y., F. J. Luizao, A. Chauvel, J. Rouiller, and D. Nahon (1993), The relationship between the biological activity of the rain forest and the mineral composition of the soils, Science, 260, 521-523.

Ma, J. F., Y. Miyake, and E. Takahashi (2001), Silicon as a beneficial element for crop plants, in Silicon in Agriculture, edited by L. E. Datnoff et al., pp. 17-40, Elsevier, New York

Mahowald, N., K. Kohfeld, M. Hansson, Y. Balkanski, S. P. Harrison, I. C. Prentice, M. Schulz, and H. Rodhe (1999), Dust sources and deposition during the Last Glacial Maximum and current climate: A comparison of model results with paleodata from ice cores and marine sediments, J Geophys. Res., 104, 895-916.

Markewitz, D., and D. D. Richter (1998), The bio in aluminum and silicon geochemistry, Biogeochemistry, 42, 235-252.

Mason, J. A., P. M. Jacobs, P. R. Hanson, X. Miao, and R. J. Goble (2003), Sources and paleoclimatic significance of Holocene Bignell loess, central Great Plains, USA, Quat. Res., 60, 330-339.

McCulley, R. F., and I. C. Burke (2004), Microbial community composition across the Great Plains: Landscape versus regional variability, Soil Sci. Soc. Am. J., 68, 106-115.

McNaughton, S. J., J. L. Tarrants, M. M. McNaughton, and R. H. Davis (1985), Silica as a defense against herbivory and a growth promoter in African grasses, Ecology, 66, 528-535.

Meunier, J. D., F. Colin, and C. Alarcon (1999), Biogenic silica storage in soils, Geology, 27, 835-838

Mortlock, R. A., and P. N. Froelich (1989), A simple method for the rapid determination of biogenic opal in pelagic marine sediments, Deep Sea Res., 36, 1415-1426.

National Climatic Data Center (2002), U.S. Monthly Climate Normals 1971-2000, NOAA, Asheville, N. C.

Oviatt, C. G. (1998), Geomorphology of Konza Prairie, in Long-Term Ecological Research in Tallgrass Prairie, edited by A. K. Knapp, pp. 47-53, Oxford Univ. Press, New York.

Parr, J. F. (2002), A comparison of heavy liquid floatation and microwave digestion techniques for the extraction of fossil phytoliths from sediments, Rev. Palaeobot. Palynol., 120, 315-336.

Parr, J. F., C. J. Lentfer, and W. E. Boyd (2001), A comparative analysis of wet and dry ashing techniques for the extraction of phytoliths from plant material, J Archaeol. Sci., 28, 875-886.

Piperno, D. R. (1988), Phytolith Analysis: An Archaeological and Geological Perspective, 280 pp., Elsevier, New York.

Raven, J. A. (1983), The transport and function of silicon in plants, Biol. Rev. 58, 179-207.

Roberts, H. M., D. R. Muhs, A. G. Wintle, G. A. T. Duller, and E. A. Bettis III (2003), Unprecedented last-glacial mass accumulation rates determined by luminescence dating of loess from western Nebraska, Quat. Res., 59, 411-419.

Sangster, A. G., and M. J. Hodson (1992), Silica deposition in subterranean organs, in Phytolith Systematics, edited by G. Rapp Jr. and S. C. Mulholland, pp. 239-251, Springer, New York.

Soil Survey Staff (1992), Soil Survey Manual, Handbook 18, U. S. Gov. Print. Off., Washington, D. C.

Soil Survey Staff (1996), Keys to Soil Taxonomy, 7th ed., USDA-NRCS, Lincoln, Nebr. 
Stromberg, C. A. E. (2004), Using phytolith assemblages to reconstruct the origin and spread of grass-dominated habitats in the great plains of North America during the late Eocene to early Miocene, Palaeogeogr. Palaeoclimatol. Palaeoecol., 207, 239-275.

Treguer, P., D. M. Nelson, A. J. Van Bennekom, D. J. DeMaster, A. Leynaert, and B. Queguiner (1995), The silica balance in the world ocean: A reestimate, Science, 268, 375-379.

White, A. F., and A. E. Blum (1995), Effects of climate on chemical weathering in watersheds, Geochim. Cosmochim. Acta, 59, 1729-1747.

White, A. F., A. E. Blum, M. S. Schulz, D. V. Vivit, D. A. Stonestrom, M. Larsen, S. F. Murphy, and D. Eberl (1998), Chemical weathering in a tropical watershed, Luquillo Mountains, Puerto Rico: I. Long-term versus short-term weathering fluxes, Geochim. Cosmochim. Acta, 62, $209-226$.

White, R., S. Murray, and M. Rohweder (2000), Pilot analysis of global ecosystems: Grassland ecosystems, report, World Resour. Inst., Washington, D. C
Wilding, L. P., and L. R. Drees (1971), Biogenic opal in Ohio soils, Soil Sci. Soc. Am. Proc., 35, 1004-1009.

Ziegler, K., O. A. Chadwick, A. F. White, and M. A. Brzezinski (2005), ${ }^{30}$ Si systematics in a granitic saprolite, Puerto Rico, Geology, 33, $817-$ 820

S. W. Blecker, Department of Forest Resources, University of Idaho, Moscow, ID 83843-1133, USA. (sblecker@uidaho.edu)

O. A. Chadwick, Department of Geography, University of California, Santa Barbara, CA 93106, USA.

E. F. Kelly, Department of Soil and Crop Sciences, Colorado State University, Fort Collins, CO 80521, USA.

R. L. McCulley, Department of Plant and Soil Science, University of Kentucky, Lexington, KY 40506, USA. 